ORIGINAL ARTICLE / ARTIGO ORIGINAL

Inequalities in the use of health services by adults and elderly people with and without noncommunicable diseases in Brazil, 2019 National Health Survey

\title{
Desigualdades na utilização de serviços de saúde por adultos e idosos com e sem doenças crônicas no Brasil, Pesquisa Nacional de Saúde 2019
}

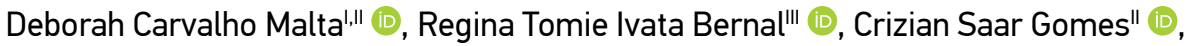 \\ Laís Santos de Magalhães Cardoso'II @ (1) Margareth Guimarães Limalv (1), \\ Marilisa Berti de Azevedo Barrosı ${ }^{\text {(1) }}$
}

\begin{abstract}
Objective: The objective of this study was to investigate the use of health services and limitations in performing usual activities by adults and elderly people with and without noncommunicable chronic diseases (NCDs), according to sociodemographic strata. Methods: This is a cross-sectional study in which data from the 2019 National Health Survey were analyzed. The final sample corresponded to 88,531 households with interviews carried out, referring to individuals aged 18 years and above. The prevalence of use of services by the population with NCDs was compared with that of the population without NCDs and stratified by socioeconomic and demographic variables. Prevalence ratios (PRs) and 95\% confidence intervals (95\%CI) were calculated. Results: In 2019, 47.6\% (95\%CI 47.0-48.3) of the population reported having one or more NCDs. Population with NCDs had more medical consultations in the last 12 months (adjusted PR [APR]=1.21; $95 \% \mathrm{CI} 1.20-1.23$ ), used more health services in the last 2 weeks ( $\mathrm{APR}=2.01 ; 95 \% \mathrm{CI} 1.91-2.11$ ), were referred to more hospitalization ( $\mathrm{APR}=2.11 ; 95 \% \mathrm{CI} 1.89-2.36$ ), and had more limitations in performing usual activities $(A P R=2.52 ; 95 \% C I$ 2.30-2.76), compared with the population without NCDs. A positive dose-response gradient was observed between the number of comorbidities and the use of services. In all socioeconomic and demographic strata, the prevalence of indicators was higher in people with NCDs. Conclusion: The presence of NCDs was associated with a higher frequency of use of health services (i.e., consultation, use of services, and hospitalization) and the restriction of usual activities in all socioeconomic and demographic strata.
\end{abstract}

Keywords: Noncommunicable chronic diseases. Health services accessibility. Health status disparities. Health surveys.

'Department of Maternal and Child Nursing and Public Health, School of Nursing, Universidade Federal de Minas Gerais - Belo Horizonte (MG), Brazil.

"Postgraduate Program in Public Health, Faculty of Medicine, Universidade Federal de Minas Gerais - Belo Horizonte (MG), Brazil. I'Postgraduate Program in Nursing, School of Nursing, Universidade Federal de Minas Gerais - Belo Horizonte (MG), Brazil.

IvDepartment of Collective Health, Faculty of Medical Sciences, Universidade de Campinas - Campinas (SP), Brazil.

Corresponding author: Deborah Carvalho Malta. Avenida Professor Alfredo Balena, 190, Santa Efigênia, CEP: 30130-100, Belo Horizonte (MG), Brazil. E-mail: dcmalta@uol.com.br

Conflicts of interest: nothing to declare - Financial support: National Health Fund, Health Surveillance Bureau (Secretaria de Vigilância em Saúde - SVS), Ministry of Health (TED 66/2018). 
RESUMO: Objetivo: Investigar a utilização de serviços de saúde e a limitação das atividades habituais entre adultos e idosos com e sem doenças crônicas não transmissíveis, segundo estratos sociodemográficos. Métodos: Estudo transversal, no qual foram analisados dados da Pesquisa Nacional de Saúde de 2019. A amostra final correspondeu a 88.531 domicílios, com entrevistas referentes a indivíduos maiores de 18 anos. As prevalências de uso de serviços pela população com doenças crônicas não transmissíveis foram comparadas às da população sem essas patologias e estratificadas por variáveis socioeconômicas e demográficas. Razões de prevalência (RP) e intervalos de confiança de 95\% foram calculados. Resultados: Em 2019, 47,6\% (IC95\% 47,0-48,3) da população referiu ter uma ou mais doenças crônicas não transmissíveis. A população com registro dessas patologias realizou mais consulta médica nos últimos 12 meses (RPaj=1,21; IC95\% 1,20-1,23), utilizou mais o serviço de saúde nas duas últimas semanas (RPaj=2,01; IC95\% 1,91-2,11), referiu mais internações (RPaj=2,11; IC95\% 1,89-2,36) e mais limitação da realização de atividades (RPaj=2,52 vezes; IC95\% 2,30-2,76) em comparação com a população isenta desse tipo de registro. Observou-se gradiente dose-resposta positivo entre número de comorbidades e uso de serviços. Em todos os estratos socioeconômicos e demográficos, a prevalência dos indicadores foi mais elevada em pessoas com doenças crônicas não transmissíveis. Conclusão: A presença dessas doenças associou-se à maior frequência de uso de serviços de saúde (consulta médica, uso de serviços de saúde e internação) e da restrição das atividades habituais em todos os estratos socioeconômicos e demográficos.

Palavras-chave: Doenças crônicas não transmissíveis. Acesso aos serviços de saúde. Desigualdades em saúde. Inquéritos epidemiológicos.

\section{INTRODUCTION}

Noncommunicable chronic diseases (NCDs) are responsible for about 41 million deaths each year, that is, $71 \%$ of all deaths in the world, of which about 15 million deaths occurred in individuals with ages between 30 and 69 years, which are, therefore, considered premature deaths ${ }^{1,2}$. Cardiovascular disease ranks first (17.9 million), followed by cancer (9.3 million), respiratory diseases $(4.1$ million $)$, and diabetes $(1.5 \text { million })^{2}$. These four groups of diseases are responsible for more than $80 \%$ of all premature deaths from $\mathrm{NCDs}^{2,3}$.

NCDs and their risk factors tend to be higher in populations of low socioeconomic status, residing in poor or marginalized communities. They also represent an important cause of the impoverishment of families and exacerbate economic inequalities within societies ${ }^{4}$.

Reducing morbidity and mortality from NCDs requires policies that considerably reduce behavioral risk factors, such as tobacco and alcohol use, reduce metabolic risk factors, such as systemic arterial hypertension, and strengthen interventions such as case follow-up, access to diagnoses, as well as the effective high-quality preventive and curative care for all who need it ${ }^{5,6}$. Therefore, coping with NCDs involves ensuring access to treatment and other care, health promotion, and prevention, as well as organizing surveillance and monitoring of these diseases, in addition to mitigating social determinants through poverty reduction and of social inequality, themes that are integrated to the Sustainable Development Goals ${ }^{2,3,7}$. 
Several studies and population surveys seek to investigate the use of health services to understand factors associated with users' demand for these services ${ }^{8,9}$. The authors highlight that the sociodemographic characteristics, socioeconomic status, available resources, provision of health services, types of health systems, among other factors, interfere in the use of health services ${ }^{10,11}$. The perception of health status and the presence of diseases also increase the demand for these services ${ }^{10}$. Analysis based on data from the 2013 Brazilian National Health Survey (Pesquisa Nacional de Saúde - PNS) identified that Brazilians with NCDs used health services more than those without such diseases and that this use increased with the expansion of the number of chronic diseases in the same individual ${ }^{7}$. Thus, it is important to monitor inequalities in the use of health services by different population segments, aiming to guide health policies that promote equity in the provision of these services and that act on other determinants of use.

From this perspective, this study aimed to investigate the use of health services and the limitation of usual activities by adults and elderly people with and without NCDs, according to sociodemographic strata.

\section{METHODS}

This is a cross-sectional study through the analysis of data from the 2019 PNS, a population-based household survey carried out by the Brazilian Institute of Geography and Statistics in partnership with the Brazilian Ministry of Health.

The PNS questionnaire was divided into three parts: the first part referring to household information, the second part referring to information from all residents, and the third part referring to information about a randomly selected individual. The PNS sampling plan consisted of a cluster sampling conducted in three stages of selection. In the first stage, the primary sampling units (PSUs) were selected by simple random sampling (SRS), consisting of census tracts or sets of census tracts (when these tracts have few households). In the second stage, a fixed number of households was chosen in each selected PSU, totaling 108,525 households. In each household selected, a resident aged 15 or above was also selected by the SRS, making up the third stage of selection ${ }^{12}$. The final sample consisted of 94,114 households with an interview, with a response rate of $93.6 \%$. In calculating the sample size, the mean values, variances, and delineation effect were considered. The databases were weighted, including a correction factor for losses ${ }^{12,13}$.

The information on access to and use of health services was obtained through the household informant (proxy informant), who answered the questions for all residents. However, in this study, only information referring to individuals aged 18 and above, who answered the specific questionnaire for the selected resident, were used; thus, the final sample analyzed consisted of 88,531 interviews.

The variables obtained in module J, related to the limitation of usual activities (J2) and the use of health services (J12, J14, and J037), were analyzed and referred to the following questions in this order: 
a) In the last 2 weeks, did you stop performing any of your usual activities (working, going to school, playing, housework, etc.) due to your own health?

b) How many times have you seen a doctor in the last 12 months?

c) In the last 2 weeks, did you look for any health service, place, or professional for care related to your own health?

d) In the last 12 months, were you hospitalized for $24 \mathrm{~h}$ or more?

From module Q, questions referring to the diagnosis of NCDs were analyzed in order to identify whether the respondent had a previous diagnosis of one or more of these pathologies, considering the positive answers for the following diseases:

1. Arterial hypertension;

2. Diabetes;

3. Heart disease and stroke;

4. Asthma;

5. Arthritis or rheumatism;

6. Work-related musculoskeletal disorder;

7. Cancer;

8. Chronic kidney failure;

9. Chronic back problem;

10. Depression; and

11. Lung disease (pulmonary emphysema, chronic bronchitis, or chronic obstructive pulmonary disease).

For most NCDs, the questions referred to previous medical diagnoses. Chronic back pain was self-reported and, in the case of depression, it was considered a previous diagnosis by a doctor or professional specialized in mental health.

The relative frequency of use of health services by the population who reported at least one NCD was compared with that of the population who declared to have no NCD, according to the following demographic and socioeconomic variables: sex (male and female), age group (18-59 years and 60 years and above), education (no education and incomplete primary, complete primary and incomplete secondary, complete secondary and incomplete higher education, and complete higher education), health plan beneficiary (yes or no), income (up to one minimum wage, higher than a minimum wage up to three minimum wages, and higher than three minimum wages), and region of residence (North, Northeast, Southeast, South, and Midwest of Brazil).

Prevalences, crude prevalence ratios (PRs), and adjusted PRs (APRs) were calculated using the Poisson model, comparing the use of health services by those who have NCD with those who have not, in each of the strata. PRs were adjusted for sex, age, and education. The APRs of use of services and limitation of usual activities were also calculated according to the number of comorbidities (having one, two, three, or four NCDs). The respective $95 \%$ confidence intervals (95\%CIs) of the PRs were also calculated. 
As the data were collected with a complex sampling plan, the statistical analysis of the data was performed using the Stata software version 14.0, through the survey module, which considers the effect of the sampling plan and the unequal selection probabilities.

PNS 2019 data are available online for public access and use (https: / www.ibge.gov. $\mathrm{br} /$ estatisticas / sociais/saude $/ 9160$-pesquisa-nacional-de-saude. $h \mathrm{tml}$ ? $=\& \mathrm{t}=$ microdados). The research was approved by the National Commission for Ethics in Research for Human Beings of the Ministry of Health (Commission Opinion No. 3,529,376 for the 2019 edition).

\section{RESULTS}

In 2019, 47.6\% (95\%CI 47.0-48.3) of Brazilian adults and elderly people reported one or more NCDs, of which $26.8 \%$ reported only one disease, $12.5 \%$ two diseases, $5.2 \%$ three diseases, and 3.2\% four or more diseases. Individuals who reported having at least one chronic disease had more frequent medical appointments in the last 12 months (89.59\%; 95\%CI 89.0790.11; APR =1.21). In all socioeconomic and demographic strata, it was observed that the presence of NCDs increases the prevalence of consultations. Some strata had a higher prevalence of medical appointments in individuals with or without NCD: women $(92.83 \%$; $95 \% \mathrm{CI}$ 92.23-93.42), elderly (93.66\%; 95\% CI 93.14-94.18), individuals with higher education $(92.84 \%$; 95\%CI 91.76-93.92) and income (93.40\%; 95\%CI 92.20-94.60), individuals with health insurance (95.57\%; 95\%CI 94.93-96.20), and residents in the Southeast (91.77\%; 95\%CI 90.89-92.65) and South (91.44\%; 95\%CI 90.43-92.46) regions. The APRs, comparing people with and without NCDs in each stratum, revealed that the presence of NCDs increased consultations in the last year among men $(\mathrm{APR}=1.31 ; 95 \% \mathrm{CI} 1.28-1.33)$, in the elderly $(\mathrm{APR}=1.27 ; 95 \% \mathrm{CI} 1.24-1.31)$, in those with less education $(\mathrm{APR}=1.32 ; 95 \% \mathrm{CI} 1.29-1.35)$ and lower income $(\mathrm{APR}=1.27 ; 95 \% \mathrm{CI}$ $\%$ 1.25-1.29), in those who do not have health insurance (APR $=1.26 ; 95 \% \mathrm{CI} 1.24-1.28)$, and among residents in the Northern $(\mathrm{APR}=1.26 ; 95 \% \mathrm{CI} 1.23-1.31)$ and Northeast $(\mathrm{APR}=1.26$; 95\%CI 1.23-1.29) regions compared with the Southeast region (Table 1).

The population with NCDs used health services more in the last 2 weeks $(30.53 \%$; $95 \% \mathrm{CI}$ 29.74-31.33; APR=2.01). The use of health services in the last 2 weeks, in all socioeconomic strata, was higher among the population with NCDs; however, the prevalence of use was higher among women (34.45\%; 95\%CI 33.36-35.53), elderly (32.92\%; 95\%CI 31.74-34.11), those with higher education (33.90\%; 95\%CI 31.85-35.95), those with high income (33.43\%; 95\%CI 31.45-35.41), those with health insurance (35.87\%; 95\%CI 34.35-37.39), and those living in the Southeast region (33.35\%; 95\%CI 31.90-34.80). The APRs, comparing those who have and those who do not have NCDs, showed that the presence of chronic disease increased the number of consultations in recent weeks in the segments with less education and lower income and without health insurance (Table 2).

Hospitalization prevalence was about twice as high (APR $=2.11 ; 95 \% \mathrm{CI} 1.89-2.36)$ among those who reported NCDs. In all sociodemographic strata, there was a higher prevalence of hospitalization in individuals with NCDs. The prevalence of hospitalization among these 
Table 1. Prevalences and PRs (crude and adjusted) of medical appointments in the last 12 months among adults and elderly people with and without NCDs, according to socioeconomic and demographic variables.

\begin{tabular}{|c|c|c|c|c|}
\hline Variables & $\begin{array}{l}\text { With NCDs }{ }^{A} \\
\%(95 \% \mathrm{Cl})\end{array}$ & $\begin{array}{c}\text { Without NCDs } \\
\%(95 \% \mathrm{Cl})\end{array}$ & $\begin{array}{l}\text { CPR } \\
\text { (A/B) }\end{array}$ & $\begin{array}{c}\text { APR (A/B) } \\
(95 \% \mathrm{Cl})\end{array}$ \\
\hline Total & $89.59(89.07-90.11)$ & $72.54(71.81-73.26)$ & 1.24 & $1.21(1.20-1.23)$ \\
\hline \multicolumn{5}{|l|}{ Sex* } \\
\hline Male & $85.31(84.41-86.20)$ & $64.27(63.16-65.38)$ & 1.33 & $1.31(1.28-1.33)$ \\
\hline Female & $92.83(92.23-93.42)$ & $80.91(80.00-81.82)$ & 1.15 & $1.14(1.13-1.16)$ \\
\hline \multicolumn{5}{|l|}{ Age range (in years) ${ }^{\dagger}$} \\
\hline $18-59$ & $87.35(86.61-88.08)$ & $72.46(71.68-73.23)$ & 1.21 & $1.20(1.19-1.22)$ \\
\hline 60 and more & $93.66(93.14-94.18)$ & $73.33(71.46-75.21)$ & 1.28 & $1.27(1.24-1.31)$ \\
\hline \multicolumn{5}{|l|}{ Education level ${ }^{\ddagger}$} \\
\hline $\mathrm{NI}$ to IES & $89.21(88.49-89.93)$ & $64.50(63.08-65.91)$ & 1.38 & $1.32(1.29-1.35)$ \\
\hline CES & $87.26(85.65-88.87)$ & $67.31(65.40-69.23)$ & 1.30 & $1.24(1.20-1.29)$ \\
\hline CHS to IHE & $89.59(88.62-90.56)$ & $74.95(73.81-76.08)$ & 1.20 & $1.17(1.15-1.20)$ \\
\hline $\mathrm{CHE}$ & $92.84(91.76-93.92)$ & $83.60(82.22-84.98)$ & 1.11 & $1.11(1.08-1.13)$ \\
\hline \multicolumn{5}{|l|}{ Income } \\
\hline$\leq 1 \mathrm{MW}$ & $87.67(86.88-88.47)$ & $67.44(66.41-68.47)$ & 1.30 & $1.27(1.25-1.29)$ \\
\hline$>1 \mathrm{MW}$ until $3 \mathrm{MW}$ & $90.80(90.01-91.58)$ & $76.62(75.52-77.73)$ & 1.19 & $1.17(1.15-1.19)$ \\
\hline$>3 \mathrm{MW}$ & $93.40(92.20-94.60)$ & $84.01(82.24-85.79)$ & 1.11 & $1.10(1.08-1.13)$ \\
\hline \multicolumn{5}{|l|}{ Health insurance } \\
\hline Yes & $95.57(94.93-96.20)$ & $87.90(86.90-88.91)$ & 1.09 & $1.08(1.07-1.10)$ \\
\hline No & $87.19(86.51-87.86)$ & $67.28(66.41-68.16)$ & 1.30 & $1.26(1.24-1.28)$ \\
\hline \multicolumn{5}{|l|}{ Region } \\
\hline North & $83.57(82.22-84.92)$ & $64.17(62.33-66.02)$ & 1.30 & $1.26(1.23-1.31)$ \\
\hline Northeast & $86.55(85.63-87.46)$ & $66.78(65.61-67.96)$ & 1.30 & $1.26(1.23-1.29)$ \\
\hline Southeast & 91.77 (90.89-92.65) & $77.87(76.56-79.18)$ & 1.18 & $1.16(1.14-1.19)$ \\
\hline South & $91.44(90.43-92.46)$ & $74.10(72.36-75.84)$ & 1.23 & $1.22(1.19-1.25)$ \\
\hline Midwest & $88.26(86.57-89.96)$ & 71.06 (68.94-73.17) & 1.24 & $1.22(1.19-1.26)$ \\
\hline
\end{tabular}

Source: PNS, 2019, Brazil.

NCDs: noncommunicable chronic diseases; 95\%Cl: 95\% confidence interval; CPR: crude prevalence ratio; APR: prevalence ratio adjusted for age, sex, and education; *PR adjusted for age and education; †PR adjusted for sex and education; fPR adjusted for sex and age; NI: no instruction; IES: incomplete elementary school; CES: complete elementary school; CHS: complete high school; IHE: incomplete higher education; CHE: complete higher education; $\mathrm{MW}$ : minimum wage. 
Table 2. Prevalences and PRs (crude and adjusted) for the use of health services in the last 2 weeks among adults and elderly people with and without noncommunicable chronic diseases, according to socioeconomic and demographic variables.

\begin{tabular}{|c|c|c|c|c|}
\hline Variables & $\begin{array}{l}\text { With NDCs }{ }^{\mathrm{A}} \\
\%(95 \% \mathrm{Cl})\end{array}$ & $\begin{array}{l}\text { Without NDCs }{ }^{B} \\
\%(95 \% \mathrm{Cl})\end{array}$ & $\begin{array}{l}\text { CPR } \\
\text { (A/B) }\end{array}$ & $\begin{array}{c}\text { APR (A/B) } \\
(95 \% \mathrm{Cl})\end{array}$ \\
\hline Total & $30.53(29.74-31.33)$ & $14.47(13.86-15.07)$ & 2.11 & $2.01(1.91-2.11)$ \\
\hline \multicolumn{5}{|l|}{ Sex* } \\
\hline Male & $25.35(24.24-26.46)$ & $11.01(10.26-11.77)$ & 2.30 & $2.14(1.96-2.33)$ \\
\hline Female & $34.45(33.36-35.53)$ & $17.96(17.01-18.91)$ & 1.92 & $1.93(1.81-2.05)$ \\
\hline \multicolumn{5}{|l|}{ Age range (in years) ${ }^{\dagger}$} \\
\hline $18-59$ & $29.21(28.20-30.23)$ & $14.25(13.61-14.89)$ & 2.05 & $2.01(1.90-2.12)$ \\
\hline 60 and more & $32.92(31.74-34.11)$ & $16.66(14.93-18.40)$ & 1.98 & $1.97(1.77-2.20)$ \\
\hline \multicolumn{5}{|l|}{ Education level ${ }^{\ddagger}$} \\
\hline $\mathrm{NI}$ to IES & $30.02(28.94-31.11)$ & $12.52(11.56-13.49)$ & 2.40 & $2.22(2.02-2.43)$ \\
\hline CES & $30.47(28.03-32.92)$ & $12.26(10.95-13.57)$ & 2.48 & $2.30(1.99-2.65)$ \\
\hline CHS to IHE & $29.59(28.05-31.14)$ & $14.57(13.51-15.63)$ & 2.03 & $1.92(1.75-2.10)$ \\
\hline $\mathrm{CHE}$ & $33.90(31.85-35.95)$ & $19.20(17.57-20.82)$ & 1.77 & $1.73(1.55-1.92)$ \\
\hline \multicolumn{5}{|l|}{ Income } \\
\hline$\leq 1 \mathrm{MW}$ & $29.53(28.42-30.65)$ & $13.08(12.28-13.88)$ & 2.26 & $2.16(2.01-2.31)$ \\
\hline$>1 \mathrm{MW}$ to $3 \mathrm{MW}$ & $30.87(29.58-32.16)$ & $14.66(13.66-15.66)$ & 2.11 & $1.97(1.82-2.14)$ \\
\hline$>3 \mathrm{MW}$ & $33.43(31.45-35.41)$ & $20.74(18.69-22.80)$ & 1.61 & $1.60(1.43-1.79)$ \\
\hline \multicolumn{5}{|l|}{ Health insurance } \\
\hline Yes & $35.87(34.35-37.39)$ & $20.87(19.41-22.32)$ & 1.72 & $1.66(1.53-1.80)$ \\
\hline No & $28.38(27.46-29.30)$ & $12.28(11.64-12.92)$ & 2.31 & $2.16(2.03-2.30)$ \\
\hline \multicolumn{5}{|l|}{ Region } \\
\hline North & $23.85(22.32-25.38)$ & $11.55(10.48-12.63)$ & 2.06 & $1.96(1.75-2.20)$ \\
\hline Northeast & $27.61(26.40-28.81)$ & $12.58(11.73-13.42)$ & 2.19 & $2.09(1.93-2.27)$ \\
\hline Southeast & $33.35(31.90-34.80)$ & $16.07(14.86-17.29)$ & 2.07 & $1.97(1.80-2.15)$ \\
\hline South & $31.22(29.61-32.83)$ & $15.98(14.60-17.36)$ & 1.95 & $1.85(1.67-2.04)$ \\
\hline Midwest & $27.75(25.71-29.78)$ & $13.14(11.90-14.37)$ & 2.11 & $2.03(1.79-2.29)$ \\
\hline \multicolumn{5}{|c|}{$\begin{array}{l}\text { Source: PNS, 2019, Brazil. } \\
\text { NCDs: noncommunicable chronic diseases; 95\%Cl: 95\% confidence interval; CPR: crude prevalence ratio; APR: } \\
\text { prevalence ratio adjusted for age, sex, and education; *PR adjusted for age and education; †PR adjusted for sex } \\
\text { and education; †PR adjusted for sex and age; NI: no instruction; IES: incomplete elementary school; CES: complete } \\
\text { elementary school; CHS: complete high school; IHE: incomplete higher education; CHE: complete higher education; } \\
\text { MW: minimum wage. }\end{array}$} \\
\hline
\end{tabular}


was higher among the elderly $(12.10 \%$; 95\%CI 11.29-12.91), among those with health insurance (12.06\%; 95\%CI 10.95-13.16), and among the residents in the Midwest region (13.56\%; 95\%CI 12.11-15.01). The APRs, comparing hospitalizations between those who have and those who do not have NCDs, showed that the presence of chronic disease increased the occurrence of hospitalizations in men ( $\mathrm{APR}=2.74$; 95\%CI 2.32-3.22), in elderly ( $\mathrm{APR}=2.82$; $95 \% \mathrm{CI} 2.25-3.54)$, in populations with less education ( $\mathrm{APR}=2.93 ; 95 \% \mathrm{CI} 2.42-3.55)$, in those without health insurance $(\mathrm{APR}=2.29 ; 95 \% \mathrm{CI} 2.01-2.60)$, and in residents of the North region $(\mathrm{APR}=2.51 ; 95 \% \mathrm{CI} 2.09-3.02)$ (Table 3$)$.

Table 3. Prevalences and PRs (crude and adjusted) for hospitalization in the last 12 months among adults and elderly people with and without NCDs, according to socioeconomic and demographic variables.

\begin{tabular}{|c|c|c|c|c|}
\hline Variables & $\begin{array}{l}\text { With NCDs }{ }^{A} \\
\%(95 \% \mathrm{Cl})\end{array}$ & $\begin{array}{c}\text { Without NCDs }{ }^{\mathrm{B}} \\
\%(95 \% \mathrm{Cl})\end{array}$ & $\begin{array}{l}\text { CPR } \\
(\mathrm{A} / \mathrm{B})\end{array}$ & $\begin{array}{c}\text { APR (A/B) } \\
(95 \% \mathrm{Cl})\end{array}$ \\
\hline Total & $10.71(10.01-11.41)$ & $4.72(4.38-5.07)$ & 2.27 & $2.11(1.89-2.36)$ \\
\hline \multicolumn{5}{|l|}{ Sex* } \\
\hline Male & $9.82(8.92-10.73)$ & $3.13(2.74-3.52)$ & 3.14 & $2.74(2.32-3.22)$ \\
\hline Female & $11.37(10.56-12.19)$ & $6.34(5.80-6.87)$ & 1.80 & $1.81(1.59-2.04)$ \\
\hline \multicolumn{5}{|l|}{ Age range (in years) ${ }^{\dagger}$} \\
\hline $18-59$ & $9.94(8.95-10.93)$ & $4.76(4.41-5.12)$ & 2.09 & $2.00(1.77-2.27)$ \\
\hline 60 and more & $12.10(11.29-12.91)$ & $4.32(3.38-5.27)$ & 2.80 & $2.82(2.25-3.54)$ \\
\hline \multicolumn{5}{|l|}{ Education level ${ }^{\ddagger}$} \\
\hline NI to IES & $11.87(10.76-12.97)$ & 3.88 (3.37-4.39) & 3.06 & $2.93(2.42-3.55)$ \\
\hline CES & $9.42(7.96-10.89)$ & $5.09(4.16-6.02)$ & 1.85 & $1.67(1.28-2.18)$ \\
\hline CHS to IHE & $9.78(8.74-10.82)$ & $4.85(4.32-5.39)$ & 2.01 & $1.88(1.60-2.21)$ \\
\hline $\mathrm{CHE}$ & $10.03(8.74-11.33)$ & $5.34(4.40-6.27)$ & 1.88 & $1.86(1.51-2.31)$ \\
\hline \multicolumn{5}{|l|}{ Income } \\
\hline$\leq 1 \mathrm{MW}$ & $11.09(10.37-11.82)$ & $4.76(4.31-5.21)$ & 2.33 & $2.17(1.92-2.45)$ \\
\hline$>1 \mathrm{MW}$ to $3 \mathrm{MW}$ & $10.53(9.24-11.82)$ & $4.43(3.88-4.98)$ & 2.38 & $2.24(1.85-2.70)$ \\
\hline$>3 \mathrm{MW}$ & $9.76(8.56-10.96)$ & $5.52(4.27-6.76)$ & 1.77 & $1.59(1.20-2.10)$ \\
\hline \multicolumn{5}{|l|}{ Health insurance } \\
\hline Yes & $12.06(10.95-13.16)$ & $6.89(6.01-7.78)$ & 1.75 & $1.70(1.44-2.00)$ \\
\hline No & $10.17(9.41-10.92)$ & $3.98(3.65-4.32)$ & 2.55 & $2.29(2.01-2.60)$ \\
\hline
\end{tabular}


Table 3. Continuation.

\begin{tabular}{|c|c|c|c|c|}
\hline Variables & $\begin{array}{l}\text { With NCDs }{ }^{A} \\
\%(95 \% \mathrm{Cl})\end{array}$ & $\begin{array}{l}\text { Without NCDs } \\
\%(95 \% \mathrm{Cl})\end{array}$ & $\begin{array}{l}\text { CPR } \\
\text { (A/B) }\end{array}$ & $\begin{array}{c}\text { APR (A/B) } \\
(95 \% \mathrm{Cl})\end{array}$ \\
\hline \multicolumn{5}{|l|}{ Region } \\
\hline North & $10.32(9.19-11.44)$ & 3.78 (3.19-4.37) & 2.73 & $2.51(2.09-3.02)$ \\
\hline Northeast & $9.74(9.04-10.44)$ & $4.06(3.58-4.55)$ & 2.40 & $2.09(183-2.39)$ \\
\hline Southeast & $10.79(9.38-12.19)$ & $4.96(4.29-5.63)$ & 2.18 & $2.09(1.69-2.59)$ \\
\hline South & $10.96(9.88-12.05)$ & $5.17(4.39-5.95)$ & 2.12 & $1.98(1.63-2.40)$ \\
\hline Midwest & $13.56(12.11-15.01)$ & $6.00(4.99-7.01)$ & 2.26 & $2.02(1.63-2.49)$ \\
\hline \multicolumn{5}{|c|}{$\begin{array}{l}\text { Source: PNS, 2019, Brazil. } \\
\text { NCDs: noncommunicable chronic diseases; } 95 \% \mathrm{Cl}: 95 \% \text { confidence interval; CPR: crude prevalence ratio; APR: } \\
\text { prevalence ratio adjusted for age, sex, and education; *PR adjusted for age and education; †PR adjusted for sex } \\
\text { and education; †PR adjusted for sex and age; NI: no instruction; IES: incomplete elementary school; CES: complete } \\
\text { elementary school; CHS: complete high school; IHE: incomplete higher education; CHE: complete higher education; } \\
\text { MW: minimum wage. }\end{array}$} \\
\hline
\end{tabular}

Adults with NCDs stopped performing usual activities due to health reasons more frequently $(13.34 \%$; 95\%CI $12.80-13.88)$ than adults without NCDs (APR $=2.52 ; 95 \% \mathrm{CI}$ 2.30-2.76). In all sociodemographic strata, the prevalence of not performing activities due to health reasons was higher in people with NCDs. Among them, the prevalence was more frequent in women $(15.91 \%$; 95\%CI $15.08-16.74)$; in elderly $(14.02 \%$; $95 \% \mathrm{CI}$ $13.15-14.89)$; in those with worse socioeconomic conditions: without education $(15.78 \%$; 95\%CI 14.92-16.64), low income (15.01\%; 95\%CI 14.25-15.76), and without health insurance $(13.89 \%$; 95\%CI 13.23-14.55); and in residents in the North (14.25; 95\%CI 13.0415.46) and Northeast regions (14.05\%; 95\%CI 13.21-14.89), compared with the South region. The APRs, comparing the limitations in carrying out usual activities between those who have and those who do not have NCDs, were higher in the population with low education and lower income, nonbeneficiary of health insurance, and living in the South region (Table 4).

When analyzing the use of health services according to the number of comorbidities (Figures 1A and 1B), a positive dose-response gradient is observed. Medical appointments by those without NCDs were $72.54 \%$ and increased to $85.78 \%, 93.08 \%, 95.90 \%$, and $97.69 \%(A P R=1.17,1.24,1.26$, and 1.26) among those who have one, two, three, or four and more NCDs, respectively. The prevalence of use of health services in the last 2 weeks was $14.47 \%$ in those without a diagnosis of NCD and increased to $25.38 \%, 32.56 \%$, $40.91 \%$, and $48.96 \%$, respectively, for those who have one, two, three, and four or more NCDs $(A P R=1.73,2.13,2.61$, and 3.02). The hospitalization prevalence in the last year was $4.72 \%$ among those without NCDs and increased to $7.83 \%, 10.85 \%, 16.85 \%$, and 
Table 4. Prevalences and PRs (crude and adjusted) of not performing usual activities due to health reasons in the last 2 weeks among adults and elderly people with and without NCDs, according to socioeconomic and demographic variables.

\begin{tabular}{|c|c|c|c|c|}
\hline Variables & $\begin{array}{l}\text { With NCDs }{ }^{\mathrm{A}} \\
\%(95 \% \mathrm{Cl})\end{array}$ & $\begin{array}{c}\text { Without NCDs }{ }^{\mathrm{B}} \\
\%(95 \% \mathrm{Cl})\end{array}$ & $\begin{array}{l}\text { CPR } \\
(\mathrm{A} / \mathrm{B})\end{array}$ & $\begin{array}{c}\text { APR (A/B) } \\
(95 \% \mathrm{Cl})\end{array}$ \\
\hline Total & $13.34(12.80-13.88)$ & $4.82(4.46-5.19)$ & 2.77 & $2.52(2.30-2.76)$ \\
\hline \multicolumn{5}{|l|}{ Sex ${ }^{*}$} \\
\hline Male & $9.94(9.24-10.64)$ & $3.71(3.25-4.18)$ & 2.68 & $2.49(2.15-2.87)$ \\
\hline Female & $15.91(15.08-16.74)$ & $5.94(5.39-6.50)$ & 2.68 & $2.55(2.28-2.85)$ \\
\hline \multicolumn{5}{|c|}{ Age range (in years) ${ }^{\dagger}$} \\
\hline $18-59$ & $12.97(12.27-13.67)$ & $4.70(4.31-5.08)$ & 2.76 & $2.59(2.35-2.85)$ \\
\hline 60 and more & 14.02 (13.15-14.89) & $6.09(4.98-7.21)$ & 2.30 & $2.15(1.77-2.62)$ \\
\hline \multicolumn{5}{|l|}{ Education level ${ }^{\ddagger}$} \\
\hline NI to IES & $15.78(14.92-16.64)$ & $5.27(4.61-5.92)$ & 3.00 & $2.85(2.47-3.29)$ \\
\hline CES & $12.43(10.94-13.92)$ & $4.63(3.84-5.43)$ & 2.68 & $2.63(2.12-3.28)$ \\
\hline CHS to IHE & 11.45 (10.43-12.47) & $4.53(3.92-5.15)$ & 2.53 & $2.44(2.08-2.86)$ \\
\hline $\mathrm{CHE}$ & $10.23(9.07-11.39)$ & $5.04(4.15-5.94)$ & 2.03 & $2.04(1.65-2.52)$ \\
\hline \multicolumn{5}{|l|}{ Income } \\
\hline$\leq 1 \mathrm{MW}$ & $15.01(14.25-15.76)$ & $5.21(4.68-5.74)$ & 2.88 & $2.54(2.26-2.85)$ \\
\hline$>1 \mathrm{MW}$ to $3 \mathrm{MW}$ & $12.24(11.33-13.14)$ & $4.02(3.52-4.52)$ & 3.04 & $2.81(2.41-3.28)$ \\
\hline$>3 \mathrm{MW}$ & $10.22(8.97-11.48)$ & $5.61(4.33-6.89)$ & 1.82 & $1.84(1.43-2.38)$ \\
\hline \multicolumn{5}{|l|}{ Health insurance } \\
\hline Yes & $11.98(11.01-12.95)$ & $5.81(4.91-6.70)$ & 2.06 & $1.96(1.64-2.35)$ \\
\hline No & 13.89 (13.23-14.55) & $4.49(4.10-4.87)$ & 3.10 & $2.75(2.48-3.05)$ \\
\hline \multicolumn{5}{|l|}{ Region } \\
\hline North & $14.25(13.04-15.46)$ & $5.42(4.71-6.13)$ & 2.63 & $2.39(2.03-2.83)$ \\
\hline Northeast & $14.05(13.21-14.89)$ & $5.62(5.02-6.23)$ & 2.50 & 2.27 (1.99-2.59) \\
\hline Southeast & $13.02(12.03-14.00)$ & $4.62(3.89-5.35)$ & 2.82 & $2.56(2.14-3.06)$ \\
\hline South & $12.55(11.40-13.70)$ & $3.63(3.01-4.26)$ & 3.45 & $3.11(2.55-3.80)$ \\
\hline Midwest & $13.74(12.25-15.24)$ & $4.61(3.77-5.44)$ & 2.98 & $2.81(2.27-3.49)$ \\
\hline
\end{tabular}

Source: PNS, 2019, Brazil.

NCDs: noncommunicable chronic diseases; $95 \% \mathrm{Cl}$ : 95\% confidence interval; CPR: crude prevalence ratio;

APR: prevalence ratio adjusted for age, sex, and education; *PR adjusted for age and education; †PR adjusted for sex and education; †PR adjusted for sex and age; NI: no instruction; IES: incomplete elementary school; CES: complete elementary school; CHS: complete high school; IHE: incomplete higher education; CHE: complete higher education; MW: minimum wage. 
A

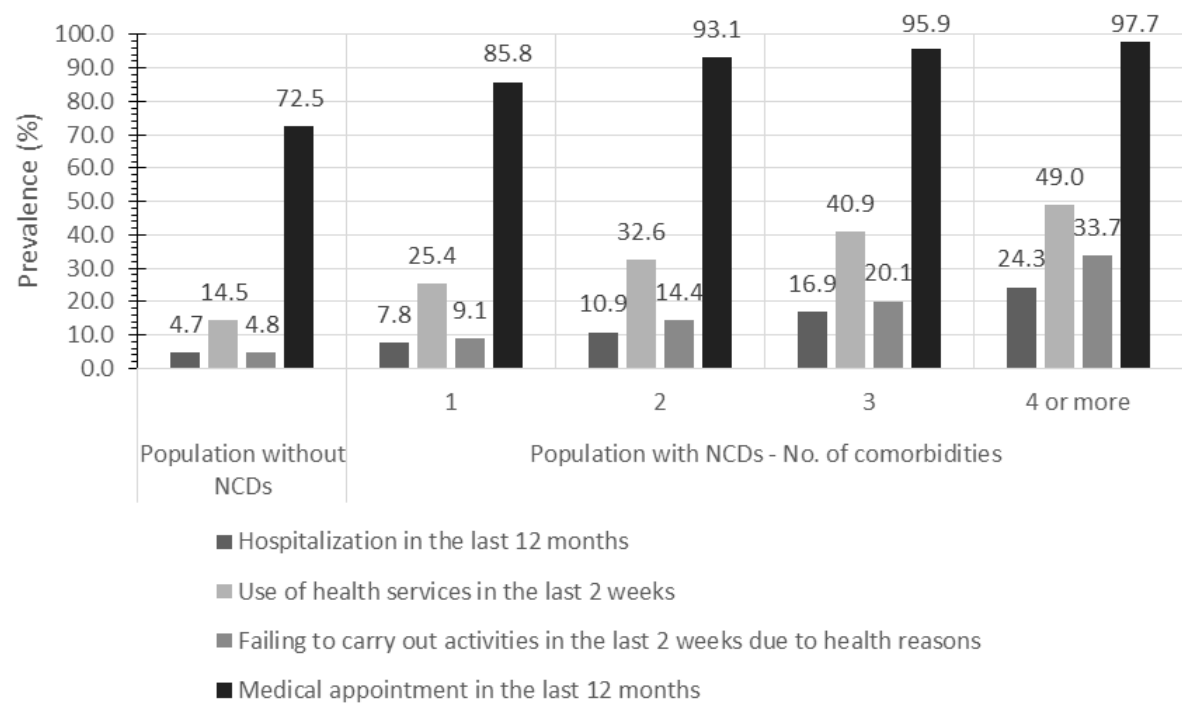

$\mathrm{B}$

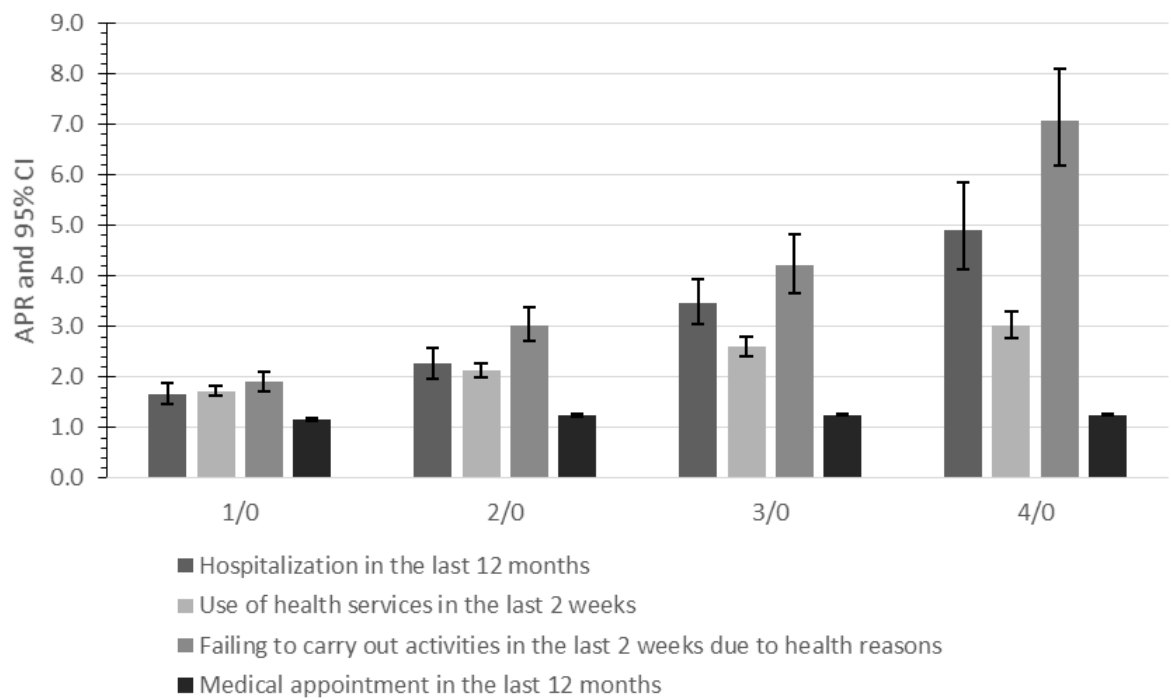

Source: Own elaboration. PNS data, 2019.

NCDs: noncommunicable chronic diseases; APR: adjusted prevalence ratio; $95 \% \mathrm{Cl}$ : $95 \%$ confidence interval; 0: absence of noncommunicable chronic diseases; 1: presence of one noncommunicable chronic disease; 2: presence of two noncommunicable chronic diseases; 3: presence of three noncommunicable chronic diseases; and 4: presence of four noncommunicable chronic diseases.

Figure 1. Prevalences $(A)$ and prevalence ratios $(B)$ for use of services and limitation of usual activities among adults and elderly people with and without chronic noncommunicable diseases, according to the number of diseases reported by the same individual. PNS, 2019, Brazil. 
$24.30 \%$ for those with one, two, three, and four or more NCDs, respectively (APR $=1.66$, $2.26,3.46$, and 4.91). Likewise, the prevalence of not performing usual activities due to health reasons increased with an increase in the number of comorbidities, from $4.82 \%$, among those who do not have it, to $9.1 \%, 14.4 \%, 20.1 \%$, and $33.7 \%$ among those who have one, two, three, and four or more, respectively $(A P R=1.92,3.03,4.20$, and 7.06) (Figures $1 \mathrm{~A}$ and $\mathrm{B}$ ).

\section{DISCUSSION}

The results show that almost half of adults and elderly people reported having one or more NCDs, and the use of health services was more intense by this population. Those who reported having NCDs showed a $21 \%$ increase in medical appointments in the last 12 months; a $100 \%$ increase in the use of health services in the last 2 weeks; a $110 \%$ increase in the occurrence of hospitalization; and a $152 \%$ increase in limiting the performance of usual activities.

The number of comorbidities also influenced the use of health services, reaching about five times more hospitalizations among those with four or more comorbidities. Socioeconomic and demographic factors also influence the use of these services. In general, women and elderly people use health services more, as well as individuals with better socioeconomic conditions, who have health insurance, higher education, and income, and live in the Southeast region. In contrast, not performing usual activities due to health reasons was more frequent in those with worse socioeconomic conditions (without health insurance, with less education, and have an income below the minimum wage), pointing to social inequalities.

This study identified that almost half of Brazilian adults and elderly people reported at least one NCD. These chronic diseases represent the greatest burden of disease in the world; the prevalence increases with age and among the most vulnerable populations ${ }^{4,14,15}$, making it a greater challenge in terms of equating access to health services.

Studies have shown that individuals with NCDs are among the users of health systems that most demand actions, procedures, longitudinal monitoring, and health services due to the high burden of diseases and the long period of evolution and impairment ${ }^{7,17}$. This study identified that the use of health services in the last 2 weeks, as well as hospitalization in the last 12 months, was about twice as high among users with NCDs. All indicators were higher in those with NCDs (medical appointments, use of health services, hospitalization, not performing usual activities), which was described in another study due to the greater disability related to these comorbidities ${ }^{17}$.

The greater demand and, consequently, use of health services by those with NCDs have been shown in other studies ${ }^{18,19}$. Some authors emphasized that the use of health services stems from the perception of the severity of the disease, feelings such as pain or disability, as well as the feeling that the search for these services can help alleviate suffering ${ }^{8,11}$. 
In addition, NCDs monitoring protocols indicate the need for longitudinal monitoring of the primary health care (PHC) services, naturally expanding the use of health services by these populations ${ }^{20}$.

This study also identified a significant increase in the use of health services as the number of comorbidities increased. People with four or more NCDs used about three times more health services compared with those without them. The greater use can be justified by the severity of the disease, multimorbidity, and complications ${ }^{7,8,21}$.

In this study, elderly people with NCDs had more medical appointments and more hospitalizations. In general, the use of health services and care by this age group, as well as access to them, is relatively high ${ }^{22}$. Analysis of data from the Brazilian Longitudinal Study of Aging (Estudo Longitudinal de Saúde dos Idosos Brasileiros - ELSI-Brazil) identified that $83 \%$ of individuals aged 50 years and above had at least one medical appointment in the last 12 months, of which the largest proportion comprised those with access to a health insurance plan ${ }^{22}$. Furthermore, elderly people with multimorbidity, health insurance, and residing in areas covered by the Family Health Strategy are more hospitalized ${ }^{23}$.

Some authors have described greater use of health services by women ${ }^{8,11,24}$, which was found in the current study. These characteristics have been explained by the greater perception of risk and greater care of women for seeking these services early and undergoing more tests and procedures with a greater chance of diagnosis, prevention, and treatment. This study also pointed out that women without NCDs uses health services more (higher prevalence) than men.

However, data not presented in this study showed that men with four or more comorbidities had more hospitalizations in the last year ( 28.2 versus $22.2 \%$ in women), which can be explained by the greater severity of the health status, lower demand for health services, and less longitudinal follow-up by males. Studies have shown that mortality rates from NCDs are higher among men, as well as a higher prevalence of risk factors, such as tobacco, systemic arterial hypertension, alcohol, obesity, among others ${ }^{17,25}$.

Differences were also observed in the use of health services due to socioeconomic conditions. Individuals with higher education, higher income, and health plan beneficiaries had more medical appointments and more access to health services compared with those with lower income. A similar situation was identified in the National Household Sample Survey (PNAD) in 2003 and in the PNS in $2013^{7,24}$. Socioeconomic conditions are associated with more access to health services, whether due to greater availability of financial resources, better clarification on the importance of access to these services, and more availability and offer of network of services in health plans. ${ }^{7,24}$. Furthermore, evidence indicates that health plan users have more access to health consultations and procedures ${ }^{7,26,27}$, as well as they have more access to a wider and more funded service network ${ }^{26}$.

However, regarding hospitalization, there was no difference according to socioeconomic conditions, which indicates the importance and extent of Brazil's Unified Health System in providing health care in the country for more than $75 \%$ of the Brazilian population. Only the strengthening of the SUS will make it possible to reduce the existing 
inequalities and guarantee universal access, integrality, and equity. It is noteworthy here that the freeze on public health expenditure, due to Constitutional Amendment No. $95 / 2016$, may, in the short term, lead to a setback. It is urgent to recover and expand the SUS funding ${ }^{28}$.

Researches show that economic disparity is an important explanatory factor for inequalities in the use of health services, indicating that low-income population segments, despite having more health needs, use these services less and receive less health care ${ }^{4,29,30}$. A study with a South African population argues that this context may be related to the lack of social structure and financial support, which are the conditions that limit the access to health services, either because of the distance or because of the inability to bear the costs of traveling ${ }^{30}$.

Studies have shown that the burden of NCDs is higher in low- and middle-income countries, where NCDs mortality rates are almost twice as high as in high-income countries ${ }^{31}$. The double burden of disease burdens health systems in these countries ${ }^{32}$, which is also made worse by the lack of access to PHC and its high costs ${ }^{33}$. The current study reveals that, in Brazil, unlike other countries, the SUS has shown its ability to meet and respond to the demands of access of the population with NCDs and greater social vulnerability, ensuring better access to medical appointments and the use of services health care and hospitalizations, compared with the population without diseases. However, there were differences between socioeconomic groups.

It is noteworthy that the greatest inequality in the current study was found in the restriction of performing usual activities due to a health problem, with a greater degree of limitation in 2 weeks before the survey. In short, low-income populations had more disadvantages and limitations in daily life.

Among the limitations of this study, the cross-sectional design stands out, which, although advantageous due to its speed and low cost, adds inherent disadvantages, such as the possibility of reverse causality. Self-reported medical diagnosis depends on access to health services, which may be lower in more vulnerable populations. In addition, this study used two different modules of the PNS: the selected resident answered about the self-reported NCDs, while the health services use module (module J) was answered by one of the residents, not necessarily the one drawn, which can lead to an underreporting of information on the use of health services.

From the data analyzed in this study, it was concluded that people with NCDs used health services more, as well as women, people with a greater number of comorbidities, with a health insurance plan, and with a high level of education. Investing in SUS is essential to improve NCDs indicators in the country, which includes strengthening the health system, financing, governance, management, human resources in health, health information, and access to technologies and medicines ${ }^{4,7}$. Knowing the differences in the access to and the use of health services can guide the design of public policies for inclusion which promotes equity and sustainability of actions within the scope of the SUS. 


\section{ACKNOWLEDGMENT}

Malta DC thanks the National Council for Scientific and Technological Development (Conselho Nacional de Desenvolvimento Científico e Tecnológico-CNPq), which financed the research productivity grant.

\section{REFERENCES}

1. World Health Organization. Noncommunicable diseases progress monitor 2020. Genebra: World Health Organization; 2020. Available at: https: / / www.who. int/publications/i/item/ncd-progress-monitor-2020

2. World Health Organization. Noncommunicable diseases. Genebra: World Health Organization; 2021 Available at: https://www.who.int/news-room/ fact-sheets/detail/noncommunicable-diseases

3. GBD 2015 Risk Factors Collaborators. Global, regional, and national comparative risk assessment of 79 behavioural, environmental and occupational, and metabolic risks or clusters of risks, 1990-2015: a systematic analysis for the Global Burden of Disease Study 2015. Lancet 2016; 388(10053): 1659-724. https: / / doi.org/10.1016/S0140-6736(16)31679-8. Erratum in: Lancet 2017; 389(10064): e1. https: / doi.org/10.1016/ S0140-6736(16)32632-0

4. Di Cesare M, Khang YH, Asaria P, Blakely T, Cowan MJ, Farzadfar F, et al. Inequalities in non-communicable diseases and effective responses. Lancet 2013; 381(9866): 585-97. https:// doi.org/10.1016/S0140-6736(12)61851-0

5. NCD Countdown 2030 collaborators. NCD Countdown 2030: worldwide trends in noncommunicable disease mortality and progress towards Sustainable Development Goal target 3.4. Lancet 2018; 392(10152): 1072-88. https:/ / doi.org/10.1016/ S0140-6736(18)31992-5

6. Nugent R, Bertram MY, Jan S, Niessen LW, Sassi F, Jamison DT, et al. Investing in non-communicable disease prevention and management to advance the Sustainable Development Goals. Lancet 2018; 391(10134): 2029-35. https: / / doi.org/10.1016/S01406736(18)30667-6. Erratum in: Lancet 2018; 391(10134): 1996. https:// doi.org/10.1016/S0140-6736(18)30852-3

7. Malta DC, Bernal RTI, Lima MG, Araújo SSC, Silva MMA, Freitas MIF, et al. Noncommunicable diseases and the use of health services: analysis of the National Health Survey in Brazil. Rev Saúde Pública 2017; 51(suppl 1): 4s. https: / / doi.org/10.1590/ s1518-8787.2017051000090

8. Pinheiro RS, Viacava F, Travassos C, Brito AS. Gênero, morbidade, acesso e utilização de serviços de saúde no Brasil. Cienc Saude Colet 2002; 7(4): 687-707. https: / / doi.org/10.1590/S1413-81232002000400007

9. Stopa SR, Malta DC, Monteiro CN, Szwarcwald CL, Goldbaum M, Cesar CLG. Use of and access to health services in Brazil, 2013 National Health Survey. Rev Saúde Pública 2017; 51(suppl 1): 3s. https: / / doi. org/10.1590/s1518-8787.2017051000074

10. Barros MBA, Cesar CLG, Carandina L, Torre GD. Desigualdades sociais na prevalência de doenças crônicas no Brasil, PNAD-2003. Cien Saude Colet 2006; 11(4): 911-26. https:// doi.org/10.1590/ S1413-81232006000400014

11. Travassos C, Martins M. Uma revisão sobre os conceitos de acesso e utilização de serviços de saúde. Cad Saúde Pública 2004; 20(suppl 2): S190-S198. https:// doi. org/10.1590/S0102-311X2004000800014

12. Stopa SR, Szwarcwald CL, Oliveira MM, Gouvea ECDP, Vieira MLFP, Freitas MPS, et al. Pesquisa Nacional de Saúde 2019: histórico, métodos e perspectivas. Epidemiol Serv Saúde 2020; 29(5): e2020315. http:/ / doi.org/10.1590/s1679-49742020000500004

13. Instituto Brasileiro de Geografia e Estatística. Pesquisa nacional de saúde: 2019: informações sobre domicílios, acesso e utilização dos serviços de saúde: Brasil, grandes regiões e unidades da federação. Rio de Janeiro: Instituto Brasileiro de Geografia e Estatística; 2020. Available at: https: / / biblioteca.ibge.gov.br/visualizacao/livros / liv101748.pdf

14. Marmot M, Bell R. Social determinants and noncommunicable diseases: time for integrated action. BMJ 2019; 364: 1251. https://doi.org/10.1136/bmj. 1251 
15. Andrade DRS, Camelo LV, Reis RC, Santos IS, Ribeiro AL, Giatti L, et al. Life course socioeconomic adversities and 10-year risk of cardiovascular disease: cross-sectional analysis of the Brazilian Longitudinal Study of Adult Health. Int J Public Health 2017; 62(2): 283-92. https:// doi.org/10.1007/s00038-016-0928-3

16. Instituto Brasileiro de Geografia e Estatística. Pesquisa nacional de saúde: 2013: acesso e utilização dos serviços de saúde, acidentes e violências: Brasil, grandes regiões e unidades da federação. Rio de Janeiro: Instituto Brasileiro de Geografia e Estatística; 2015. Available at: https:/ / biblioteca.ibge.gov.br/visualizacao/livros/ liv94074.pdf

17. GBD 2019 Diseases and Injuries Collaborators. Global burden of 369 diseases and injuries in 204 countries and territories, 1990-2019: a systematic analysis for the Global Burden of Disease Study 2019. Lancet 2020; 396(10258): 1204-22. https:// doi.org/10.1016/S0140-6736(20)30925-9. Erratum in: Lancet 2020; 396(10262): 1562. https:// doi. org/10.1016/S0140-6736(20)32226-1

18. Dalstra JAA, Kunst AE, Borrell C, Breeze E, Cambois E, Costa G, et al. Socioeconomic differences in the prevalence of common chronic diseases: an overview of eight European countries. Int J Epidemiol 2005; 34(2): 316-26. https: / / doi.org/10.1093/ije/dyh386

19. Cricelli C, Mazzaglia G, Samani F, Marchi M, Sabatini A, Nardi R, et al. Prevalence estimates for chronic diseases in Italy: exploring the differences between self-report and primary care databases. J Public Health Med 2003; 25(3): 254-7. https://doi.org/10.1093/ pubmed/fdg060

20. Brasil. Ministério da Saúde. Secretaria de Atenção à Saúde. Departamento de Atenção Básica. Estratégia para o cuidado da pessoa com doença crônica. Brasília: Ministério da Saúde; 2014. Available at: http:/ / bvsms. saude.gov.br/bvs/publicacoes/estrategias_cuidado_ pessoa_doenca_cronica_cab35.pdf

21. Nunes BP, Chiavegatto Filho ADP, Pati S, Teixeira DSC, Flores TR, Camargo-Figueira FA, et al. Contextual and individual inequalities of multimorbidity in Brazilian adults: a cross-sectional national-based study. BMJ Open 2017; 7: e015885. https://doi.org/10.1136/ bmjopen-2017-015885. Erratum in: BMJ Open 2019; 9(11): e015885corr2http:/ / doi.org/10.1136/ bmjopen-2017-015885 corr2

22. Macinko J, Andrade FB, Souza Junior PRB, Lima-Costa MF. Primary care and healthcare utilization among older Brazilians (ELSI-Brazil). Rev Saúde Pública 2018; 52(Suppl 2): 6s. https:// doi.org/10.11606/ s1518-8787.2018052000595
23. Nunes BP, Soares MU, Wachs LS, Volz PM, Saes MO, Duro SMS, et al. Hospitalização em idosos: associação com multimorbidade, atenção básica e plano de saúde. Rev Saúde Pública 2017; 51: 43. https: / / doi. org/10.1590/S1518-8787.2017051006646

24. Barros MBA, Francisco PMSB, Zanchetta LM, Cesar CLG. Tendências das desigualdades sociais e demográficas na prevalência de doenças crônicas no Brasil, PNAD: 2003-2008. Cienc Saude Colet 2011; 16(9): 3755-68. https:// doi.org/10.1590/ S1413-81232011001000012

25. Malta DC, Duncan BB, Schmidt MI, Teixeira R, Ribeiro ALP, Felisbino-Mendes MS, et al. Trends in mortality due to non-communicable diseases in the Brazilian adult population: national and subnational estimates and projections for 2030. Popul Health Metr 2020; 18(Suppl1): 16. https:/ / doi.org/10.1186/ s12963-020-00216-1

26. Lima-Costa MF. Estilos de vida e uso de serviços preventivos de saúde entre adultos filiados ou não a plano privado de saúde (inquérito de saúde de Belo Horizonte). Cienc Saude Colet 2004; 9(4): 857-64. https: / / doi.org/10.1590/S1413-81232004000400008

27. Malta DC, Moura EC, Oliveira M, Santos FP. Usuários de planos de saúde: morbidade referida e uso de exames preventivos, por inquérito telefônico, Brasil, 2008. Cad Saúde Pública 2011; 27(1): 57-66. https:// doi.org/10.1590/S0102-311X2011000100006

28. Castro MC, Massuda A, Almeida G, Menezes-Filho NA, Andrade MV, Noronha KVMS, et al. Brazil's unified health system: the first 30 years and prospects for the future. Lancet 2019; 394(10195): 345-56. https: / / doi. org/10.1016/S0140-6736(19)31243-7

29. Xie X, Wu Q, Hao Y, Yin H, Fu W, Ning N, et al. Identifying determinants of socioeconomic inequality in health service utilization among patients with chronic non-communicable diseases in China. PLoS One 2014; 9(6): e100231. https:/ / doi.org/10.1371/ journal.pone.0100231

30. Gordon T, Booysen F, Mbonigaba J. Socio-economic inequalities in the multiple dimensions of access to healthcare: the case of South Africa. BMC Public Health 2020; 20(1): 289. https://doi.org/10.1186/ s12889-020-8368-7

31. World Health Organization. Preventing chronic diseases: a vital investment. Genebra: World Health Organization; 2005.

32. Jamison DT, Summers LH, Alleyne G, Arrow KJ, Berkley S, Binagwaho A, et al. Global health 2035: a world converging within a generation. Lancet 2013; 382(9908): 1898-955. https:// doi.org/10.1016/ S0140-6736(13)62105-4 
33. Kankeu HT, Saksena P, Xu K, Evans DB. The financial burden from non-communicable diseases in lowand middle-income countries: a literature review. Health Res Policy Syst 2013; 11: 31. https:/ / doi. org/10.1186/1478-4505-11-31

Received on: 05/31/2021

Revised on: 08/24/2021

Accepted on: 08/26/2021

Preprint on: 09/10/2021

https://preprints.scielo.org/index.php/scielo/

preprint/view/2925
Author's contributions: Malta, D.C.: Project administration, Obtaining funding, Conceptualization, Data curation, Writing-first draft, Writing-proofreading and editing. Bernal, R.T.I.: Conceptualization, Statistical analysis, Writing-first writing, Writing-proofreading and editing. Gomes, C.S.: Conceptualization, Writing - first writing, Writing - proofreading and editing. Cardoso, L.S.M.: Conceptualization, Writing - first writing, Writing - proofreading and editing. Lima, M.G.: Conceptualization, Writing - first writing, Writing - proofreading and editing. Barros, M.B.A.: Conceptualization, Writing - first writing, Writing proofreading and editing. 